\title{
The application of the deterministic chaos method in the assessment of the combustion process in diesel engines fitted in non-road vehicles
}

\begin{abstract}
The paper describes the problem of the combustion process diagnostics in diesel engines of HDV vehicles in the aspect of the environment protection and misfire detection as well as its use in the OBD/EOBD systems. Vibroacoustic processes were taken into consideration and the chosen parameters of the vibration signals obtained from the specified locations in the engine were the diagnostic estimators of the process changes. The paper discusses the diagnosis of the course of the process from the point of view of the OBD system requirements, in order to check the possibility of using the deterministic chaos method and vibroacoustic processes in on-line diagnostic processes and in the design of combustion monitors in diesel locomotive engines. This stage of the scientific studies was done to check the sensitivity of selected non-linear methods for the process changes or their lack. The paper also presents the signal analyses, limitations of the method, criteria of the process qualification and its accuracy. Diagnostic algorithms of misfire detection and possibility of its practical use in contemporary vehicle drivertrains have been described as well.
\end{abstract}

Keywords: combustion process, misfire, diagnostics, vibroacoustics, environment protection, OBD system, deterministic chaos theory

\section{Zastosowanie metody chaosu deterministycznego do oceny poprawności procesu spalania w silnikach ZS pojazdów pozadrogowych}

W artykule opisano problematykę diagnostyki procesu spalania dla silników ZS pojazdów typu HDV (Heavy-Duty Vehicles) w aspekcie ochrony środowiska naturalnego i wykrycia braku zapłonu oraz jej zastosowania w systemach OBD/ EOBD. Rozważano procesy wibroakustyczne; wybrane parametry sygnałów drgań uzyskanych z określonych miejsc na silniku stanowity estymatory diagnostyczne zmian procesu. Artykut dotyczy diagnozy przebiegu procesu z punktu widzenia wymagań diagnostyki OBD i takiego systemu. Dokonano sprawdzenia możliwości zastosowania metody chaosu deterministycznego i procesów wibroakustycznych do bieżacej diagnostyki spalania i budowy monitora diagnostycznego w silnikach lokomotyw spalinowych. Powyższy etap badań naukowych byt zrealizowany w celu kontroli wrażliwości wybranych metod nieliniowych na zmiany procesu lub jego brak. Przedstawiono również analizy sygnałów i ograniczenia zastosowania metody oraz możliwości jej praktycznego zastosowania w obecnych źródtach napędu pojazdów.

Słowa kluczowe: proces spalania, wypadanie zapłonu, diagnostyka, wibroakustyka, ochrona środowiska naturalnego, system $O B D$, teoria chaosu deterministycznego

\section{Non-linearity of internal combustion engines}

The signals obtained from the measurements compose one-dimensional time series. The time series are processed using such methods as spectral analysis and nonlinear analysis that are based on the deterministic chaos theory. The deterministic chaos theory is a description of nonlinear dynamic systems. So far, for the improvement of the monitoring, diagnostic and control of technical devices linear methods have been used. Some elements of nonlinearity were introduced but not directly in classic linear approach [10]. The deterministic chaos theory is quite good for such analyses because it uses direct nonlinear models. The deterministic chaos theory is a continuation of the classic theory of linear dynamic systems $[1,12]$. The deterministic chaos can be described as 'unpredictable long time behavior of deterministic dynamic system which is caused by the sensitivity on an initial condition'.

We must stress that nonlinear chaotic system is a fully deterministic system and it is fully predictable if we have full knowledge about the initial conditions. The chaotic system is very sensitive to even very small changes in the initial

\section{Nieliniowość silników spalinowych}

Sygnały uzyskane w pomiarach składają się z jednowymiarowych przebiegów czasowych. Przebiegi czasowe poddano procesowi przetwarzania z zastosowaniem analizy widmowej i nieliniowej, bazującej na teorii chaosu deterministycznego. Powyższa teoria służy do opisu nieliniowych systemów dynamicznych. Do tej pory w celu poprawy procesu monitorowania, diagnozowania i sterowania urządzeń technicznych stosowano zazwyczaj metody liniowe. Wprowadzano wybrane elementy nieliniowości w klasycznym podejściu liniowym, lecz nie stosowano ich bezpośrednio [10]. Teoria chaosu deterministycznego stanowi dobre narzędzie do takiej analizy z uwagi na to, iż bezpośrednio wykorzystuje modele nieliniowe. Niniejsza teoria jest rozwinięciem klasycznej teorii liniowych modeli dynamicznych $[1,12]$. Dzięki niej możliwy jest opis procesu jako „nieprzewidywalne długookresowe zachowanie deterministycznego systemu dynamicznego, spowodowane wrażliwością na warunki początkowe".

Należy podkreślić, iż nieliniowy system chaotyczny stanowi w pełni zdeterminowany system $\mathrm{i}$ jest przewidywalny, 
conditions, hence in most of the practical cases, where the initial conditions are known only with a given accuracy, it is really unpredictable. The nonlinear chaotic system can produce a signal that is irregular and seems similar to a stochastic system but its irregularity has a non-stochastic nature, and is caused by the internal nonlinearity of the dynamics. Changing the values of the parameters of a nonlinear chaotic system we can find qualitative changes of the solution, which is particularly well seen in the phase space.

Many processes in the technical area, describing electric and mechanical devices, contain nonlinear elements in their dynamics $[5,6,8]$. This can be used to improve the monitoring, diagnostic and control of technical devices. In literature we can find a term 'engineering chaos' for a description of the deterministic chaos theory application for engineering and industrial purposes [5]. The combustion engines can be a source of many signals which are good for analysis - it is enough to mention the vibration signals from sensors fitted in the engine, all acoustic signals, signals from the ionic current detectors, signals representing crankshaft angular velocity, pressure signals, and even visual signals that can for example show the engine head heating [17]. The combustion engine shows a cyclic variability of energy release from one cycle to another. In literature the cyclic variability is described in a stochastic, linear deterministic or chaotic deterministic way, and all the time we can find the discourse on the real nature of the cyclic variability $[9,14]$. The nonlinear methods started to play an important role in engine dynamic modeling. This approach can allow us a better understanding of the dynamics of engine processes $[7,8,16]$.

\section{Methodology, test stand and measurement conditions}

The paper considers the phase of the investigations that were conducted in potential operating conditions on a 2112 SSF and 16H12A engine (diesel locomotive engine) - Table 1.

The measurement signals obtained from the transducers were fed to the amplifiers where they were amplified and normalized. They were subsequently fed to the analog inputs of the data acquisition card. Measurement signals were filtered inside the card with the help of analog and digital filters and then were converted from analog to digital. The signals obtained in the data acquisition card in a digital form were stored in a computer memory. The recorded all time history courses of the measurement signals were subjected to the time selection process. In the above selection all recorded signals were divided into signal sequences including single working cycles of the internal combustion engine.

In the investigations on the SU45 diesel locomotive engine, the selection of the operating conditions of the engine was made based on the useful $\mathrm{rpm}$ and torque range of the tested engine corresponding to the operating conditions. The measurements were divided into two parts. In the first of them all cylinders of one bank were taken into consideration to check if it is possible to use the vibration characteristics in the assessment of the combustion process course for an engine being used in traction vehicles. This stage was also jeżeli występuje pełna wiedza o warunkach początkowych. Rozważany system jest bardzo wrażliwy również przy bardzo małych zmianach zachodzących w systemie, stąd w większości praktycznych zastosowań, gdy znane są warunki początkowe jedynie z zadaną dokładnością, system taki jest nieprzewidywalny. Nieliniowy system chaotyczny może wygenerować nieregularny sygnał, dzięki czemu sprawia wrażenie systemu stochastycznego, lecz jego nieregularność nie ma natury stochastycznej i jest spowodowana przez wewnętrzną nieliniowość dynamiki. Dokonując zmiany wartości parametrów nieliniowego systemu chaotycznego, można wyznaczyć jakościowe zmiany rozwiązania, co jest szczególnie dobrze widoczne podczas przestrzeni fazowej.

Wiele procesów w obszarze techniki, opisujących urządzenia elektryczne i mechaniczne, zawiera w swojej dynamice elementy nieliniowe $[5,6,8]$. Może to być wykorzystane do poprawy procesu kontroli, diagnostyki i sterowania urządzeń technicznych. W literaturze można odnaleźć określenie ,inżynieria chaosu” do opisu zastosowania teorii chaosu deterministycznego w obszarze inżynierii i przemysłu [5]. Silniki spalinowe mogą stanowić źródło wielu sygnałów przydatnych w procesie analizy - warto w tym miejscu wymienić sygnały drgań uzyskane z przetworników umieszczonych na silniku, wszystkie sygnały akustyczne, sygnały z wykrywaczy prądu jonizacji, sygnały reprezentujące prędkość obrotową wału korbowego silnika, sygnały ciśnienia oraz nawet sygnały optyczne ukazujące np. analizę termodynamiczną głowicy silnika [17]. Silnik spalinowy charakteryzuje się tzw. cykliczną zmiennością wydzielania ciepła od jednego do następnego cyklu pracy. W literaturze zmienność cyklu jest opisana w sposób stochastyczny, liniowy deterministyczny lub deterministyczny chaotyczny $[9,14]$. Metody nieliniowe zaczęły odgrywać istotna rolę w modelowaniu dynamicznym silnika. Powyższe podejście umożliwia lepsze zrozumienie procesów dynamicznych zachodzących w silniku $[7,8,16]$.

\section{Metodyka, stanowisko badawcze i warunki pomiaru}

Praca dotyczy etapu badań, które przeprowadzono na silnikach 2112 SSF i 16H12A (silnik spalinowy lokomotywy) w warunkach odzwierciedlających warunki eksploatacji powyższych pojazdów - tab. 1 .

Sygnały pomiarowe uzyskane z przetworników były kierowane do wzmacniaczy, w których poddawane były procesowi wzmocnienia i normalizacji. Następnie kierowano je na analogowe wejścia karty pomiarowej. Wewnątrz niej poddawano je procesowi filtracji z zastosowaniem filtrów analogowych i cyfrowych, po czym przetwarzano je z postaci analogowej w cyfrową. Sygnały uzyskane w karcie pomiarowej, w postaci cyfrowej, były następnie zapisywane w pamięci komputera. Zarejestrowane wszystkie przebiegi czasowe sygnałów pomiarowych poddano procesowi selekcji czasowej. W ramach powyższego procesu sygnały podzielono na przedziały zawierające cykle pracy silnika.

W badaniach przeprowadzonych na silniku lokomotywy SU45 wybór warunków pracy silnika zrealizowano, bazując 
Table 1. The features of the engines used in researches

Tablica 1. Dane techniczne silników zastosowanych $w$ badaniach

\begin{tabular}{|c|c|c|}
\hline \multirow[t]{2}{*}{ Feature/parametr } & \multicolumn{2}{|c|}{ Type of an engine/rodzaj silnika } \\
\hline & $2112 \mathrm{SSF}$ & $16 \mathrm{H} 12 \mathrm{~A}$ \\
\hline Type/rodzaj & CI, 4-stroke & CI, 4-stroke \\
\hline Cylinder bore $\times$ piston stroke: $\mathrm{D} \times \mathrm{S}[\mathrm{m}] /$ średnica cylindra $\times$ skok ttoka: $D \times S[\mathrm{~m}]$ & $0.210 \times 0.230$ & $0.135 \times 0.155$ \\
\hline Compression ratio $(\varepsilon) /$ stopień sprężania & 11.3 & 14.0 \\
\hline Engine displacement $\left(\mathrm{V}_{\mathrm{ss}}\right)$ in $\left[\mathrm{m}^{3}\right] /$ objętość skokowa silnika $(V s s) w\left[m^{3}\right]$ & $96.6 \cdot 10^{-3}$ & $26.6 \cdot 10^{-3}$ \\
\hline Type of the injection pump/rodzaj pompy wtryskowej & PLD system & $\begin{array}{l}\text { Line injection pump/ } \\
\text { rzędowa pompa wtryskowa }\end{array}$ \\
\hline Amount of valves/liczba zaworów & 4 & 4 \\
\hline $\begin{array}{l}\text { Pressure of the injector opening }\left(\mathrm{p}_{\mathrm{wtr}}\right) \text { in }[\mathrm{MPa}] / \text { ciśnienie otwarcia wtryskiwacza }\left(p_{w t r}\right) \\
w[\mathrm{MPa}]\end{array}$ & $26 \pm 0.5$ & $19 \pm 0.5$ \\
\hline Cylinder system/amount/układ cylindrów/liczba & $\mathrm{V} 12-90^{\circ}$ & $\mathrm{V} 12-60^{\circ}$ \\
\hline Mean effective pressure in $[\mathrm{MPa}] /$ średnie ciśnienie użyteczne $w[\mathrm{MPa}]$ & 1.37 & 0.77 \\
\hline Maximum of effective power $\left(\mathrm{N}_{\mathrm{e}}\right)$ in $[\mathrm{kW}] /$ znamionowa moc użyteczna $\left(N_{\mathrm{e}}\right) w[\mathrm{~kW}]$ & $1655(1500 \mathrm{rpm})$ & $257(1500 \mathrm{rpm})$ \\
\hline
\end{tabular}

used to see the differences in the sensibility of the vibration signal in each working cylinder. This helped to determinate the best and worst conditions for misfire detection based on the vibration methods.

The second research stage was used to determine the differences between signals with combustion and misfire for different working points (power changes) for 3 cylinders taken from the previous stage. In the first stage the following engine speeds were taken into consideration: 700, 900, 1080, 1300 and $1500 \mathrm{rpm}$. The following effective power was obtained: $\sim 0$ (idling run), 252, 460, 580, $667 \mathrm{~kW}$. In the second test stage all engine speeds and torques defined with the locomotive regulating unit position were taken as the working points. The test measuring points were located in the engine head and the signals were recorded in the $\mathrm{Z}$ direction (parallel to the cylinder axis forward of the piston movement).

The misfire during the tests on the $16 \mathrm{H} 12 \mathrm{~A}$ diesel locomotive engine was simulated by the disconnection of one cylinder of the engine. The acceleration sensor was fixed into the engine frame in the place, where one could define the measurement direction of acceleration. First of all, a 16-channel digital recorder TA11 was applied produced by Gould based on piezoelectric sensor 4395 produced by Brüel \& Kjær. The authors also used a data acquisition program Gould Acquire TA-D and the results analysis program DASA VIEW II.

The measurement of the 16H12A locomotive engine was performed in the following circumstances:

1) three engine speeds: $n_{1}=650-680 \mathrm{rpm}$ (idle run), $n_{2}=$ $1100 \mathrm{rpm}, \mathrm{n}_{3}=1500 \mathrm{rpm}$,

2) three measurement phases: phase 1 - sensor is fixed on cylinder 1 - all cylinders are working, phase 2 - sensor is fixed on cylinder 1 - cylinder 1 is disconnected, phase 3 - sensor is fixed on cylinder 1 - cylinder 4 is disconnected.

The sensor was fixed on the frame of cylinder 1 . The signals were recorded in three directions: parallel to the main locomotive axis, horizontal-transverse and vertical- na użytecznym zakresie prędkości obrotowej i momentu obrotowego badanego silnika, reprezentujących warunki uzyskane podczas eksploatacji. Badania podzielono na dwa etapy. W pierwszym etapie brano pod uwagę wszystkie cylindry wybranego rzędu cylindrów, w celu określenia możliwości zastosowania charakterystyk wibroakustycznych do oceny przebiegu procesu spalania silnika pojazdu trakcyjnego. Ponadto celem było również określenie różnic we wrażliwości sygnału drganiowego na powyższe procesy uzyskanego z każdego z cylindrów. W wyniku tego możliwe było określenie najlepszych i najmniej korzystnych warunków do wykrywania wypadania zapłonu z zastosowaniem metod drganiowych. Drugi etap badań zastosowano w celu określenia różnic w sygnałach dla spalania i jego braku dla różnych punktów pracy (zmiany mocy użytecznej) dla 3 cylindrów wybranych w pierwszym etapie badań.

W pierwszym etapie uwzględniono następujące prędkości obrotowe: 700, 900, 1080, 1300 i 1500 obr/min. Moc użyteczna wynosiła: 0 (bieg jałowy), 252, 460, 580, 667 kW. W drugim etapie wszystkie wartości prędkości obrotowej i momentu obrotowego silnika brano pod uwagę jako punkty pracy. Punkty pomiarowe zlokalizowano na głowicy silnika, a rejestracja sygnałów była realizowana w kierunku $\mathrm{Z}$ (równoległy do osi cylindra w kierunku poruszania się tłoka w cylindrze).

Brak zapłonu w badaniach silnika 16H12A lokomotywy był symulowany przez odłączenie dostarczania paliwa do wybranego cylindra silnika. Przetwornik przyspieszeń drgań zamocowano do silnika w miejscu, gdzie można było określić kierunek przyspieszeń. Zastosowano 16-kanałowy rejestrator TA11 Gould wykorzystujący przetwornik Brüel \& Kjær 4391, program do akwizycji danych Gould Acquire TA-D i program do ich analizy DASA VIEW II.

Pomiary na silniku 16H12A lokomotywy przeprowadzono w następujących warunkach:

1) trzy prędkości obrotowe: $n_{1}=650-680 \mathrm{obr} / \mathrm{min}$ (bieg jałowy), $\mathrm{n}_{2}=1100 \mathrm{obr} / \mathrm{min}, \mathrm{n}_{3}=1500 \mathrm{obr} / \mathrm{min}$,

2) trzy etapy pomiarowe: etap 1 - przetwornik zamocowany na cylindrze 1 - wszystkie cylindry pracują prawidłowo, 
transverse to the main locomotive axis (second and third directions were taken only to compare signals with the $\mathrm{Z}$ direction). The engine head was the place where the vibration transducers were located.

\section{JTFA vibration signals analysis}

The analysis of the vibrations that are generated by the engine, in the range of a single engine working cycle, we can state that it is a process changing in time, both in the amplitude and frequency domains, as a result of subsequent engine work phases. The application of joined selections, such as e.g. space-spectral or time-spectral selections is purposeful in the engine diagnostics. The potential wide chances for development and use are seen nowadays for methods that are being developed at present and are based on time-spectral domain analysis. The most popular are: Short Time Fourier Transform (STFT), Wavelet Transform (WT) and Wigner Ville Distribution (WVD) [15]

STFT transform consists of the FFT analysis of short sequences of a signal that can be treated as a quasi-stationary signal. The input signal extraction of the following data segments to FFT analysis is realized with the use of the moving window technique [4]. The time-spectral map of the process analyzed is obtained when the received spectra are put together. A result the STFT analysis can be treated like a series of spectra determined for local, short time segments. The method advantages are: a short time of a timefrequency map determination, an easy and intuitive results interpretation and a constant resolution for all frequencies. The result form depends on the taken time window function and signal processing parameters: a number of samples in the data segments and the time step of the analysis. The method limitation is that it is impossible to obtain a high resolution for time and frequency domains at the same time. Resolution in the time domain can be improved by using an overlapping consisting in partial interference of the analyzed signal segments to each other. An estimation amplitude and frequency error for local maximum values on a map can be minimized by an amplitude-frequency correction - AFC $[2,3]$.

The mother functions can be each function in the Wavelet transform [11]. The Morlet's function as a mother function is used in many cases because of the calculation process simplification. Its application allows using the FFT procedure in the processing, which accelerates the calculation process effectively. The result form depends mostly on the taken mother functions. This type of an analysis can be equated to a filtration with a constant relative bandwith $\Delta \mathrm{f} / \mathrm{f}_{\mathrm{s}}$. The filter position on the time-frequency map is given by scale and translation parameters (a - dilation, $\mathrm{b}$ - translation). The analysis bandwidth increases along with the translation to higher frequencies (a resolution of an analysis in the frequency domain decreases). Then, the resolution in the time domain increases, and vice versa. That feature is useful in the case of a simultaneous analysis and observation with a different time step for a rapid changeable and high-frequency processes and slow-speed low-frequency processes. The drawbacks of the method are: etap 2 - przetwornik zamocowany na cylindrze 1 - cylinder 1 rozłączony, etap 3 - przetwornik zamocowany na cylindrze 1 - cylinder 4 rozłączony.

Przetwornik zamocowano na cylindrze 1. Sygnały rejestrowano w trzech kierunkach: wzdłuż osi cylindra, prostopadle do niej w kierunku osi wału oraz prostopadle do obu kierunków (drugi i trzeci kierunek dobrano celem porównania z kierunkiem Z). Przetworniki drgań zamocowano na głowicy silnika.

\section{Analiza JTFA sygnałów}

Analizując drgania generowane przez silnik w zakresie pojedynczego cyklu jego pracy, można stwierdzić, iż jest to proces zmienny w czasie, zarówno w dziedzinie amplitudy, jak i częstotliwości, jako wynik powyższych etapów pracy silnika. Zastosowanie selekcji łączonych, np. fazowo-częstotliwościowej lub czasowo-częstotliwościowej jest celowe dla diagnostyki silnika. Potencjalnie szerokie możliwości rozwoju i zastosowania dostrzega się obecnie w rozwijanych metodach, które bazują na analizie czasowoczęstotliwościowej, wśród których najpopularniejszymi są: krótkoczasowa transformacja Fouriera (STFT - Short Time Fourier Transform), analiza falkowa (WT - Wavelet Transform) i transformacja Wignera-Ville'a (WVD - Wigner Ville Distribution) [15].

Transformacja STFT zawiera analizę FFT krótkich sekwencji sygnałów, które mogą być traktowane jako sygnał quasi-stacjonarny. Wydzielenie sygnału wejściowego powyższych segmentów danych do analizy FFT jest realizowane z zastosowaniem techniki ruchomego okna [4]. Obraz czasowo-widmowy analizowanych procesów jest uzyskiwany, gdy otrzymane widma są łączone. Wynik analizy FFT można traktować jak zbiór widm wyznaczonych dla lokalnych krótkoczasowych segmentów. Do zalet metody należą: krótki okres wyznaczenia map czasowo-częstotliwościowych, łatwa i intuicyjna interpretacja wyników i stała rozdzielczość dla całego zakresu częstotliwości. Rodzaj uzyskiwanego wyniku zależy od przyjętej funkcji okna czasowego i parametrów procesu przetwarzania sygnału: liczby danych w segmencie danych, kroku czasowego analizy. Ograniczenie metody dotyczy braku możliwości uzyskania dużej rozdzielczości w dziedzinie czasu i częstotliwości w tym samym czasie. Rozdzielczość w dziedzinie czasu może być zwiększona przez zastosowanie tzw. overlappingu, który dotyczy częściowego nakładania się analizowanych segmentów sygnału na siebie. Błąd estymacji amplitudy i częstotliwości lokalnych wartości maksymalnych na mapie może być zminimalizowany dzięki zastosowaniu korekcji amplitudowo-częstotliwościowej (AFC - amplitude-frequency correction) $[2,3]$.

Funkcjami bazowymi (macierzystymi) mogą być każde z funkcji w przekształceniu falkowym [11]. Funkcja Morleta jako funkcja bazowa jest stosowana w wielu przypadkach z uwagi na uproszczenie procesu obliczeniowego. Zastosowanie jej umożliwia uwzględnienie procedury FFT w procesie przetwarzania sygnału, co znacząco zwiększa prędkość obliczeń. Forma wyników zależy głównie od przyjętych funkcji bazowych (macierzystych). Ten rodzaj analizy 
the form of the result depends on a taken mother function and the interpretation of a graphical form of a result is not always intuitive.

Wigner-Ville distribution (WVD) is realized by two-dimensional time-frequency window. This kind of an analysis allows taking any size of an analysis window theoretically. When an analysis window size is defined arbitrarily, it may give negative distribution values, arising interferences in the time and frequency domains, which makes the interpretation process more difficult. The WVD distribution characterizes

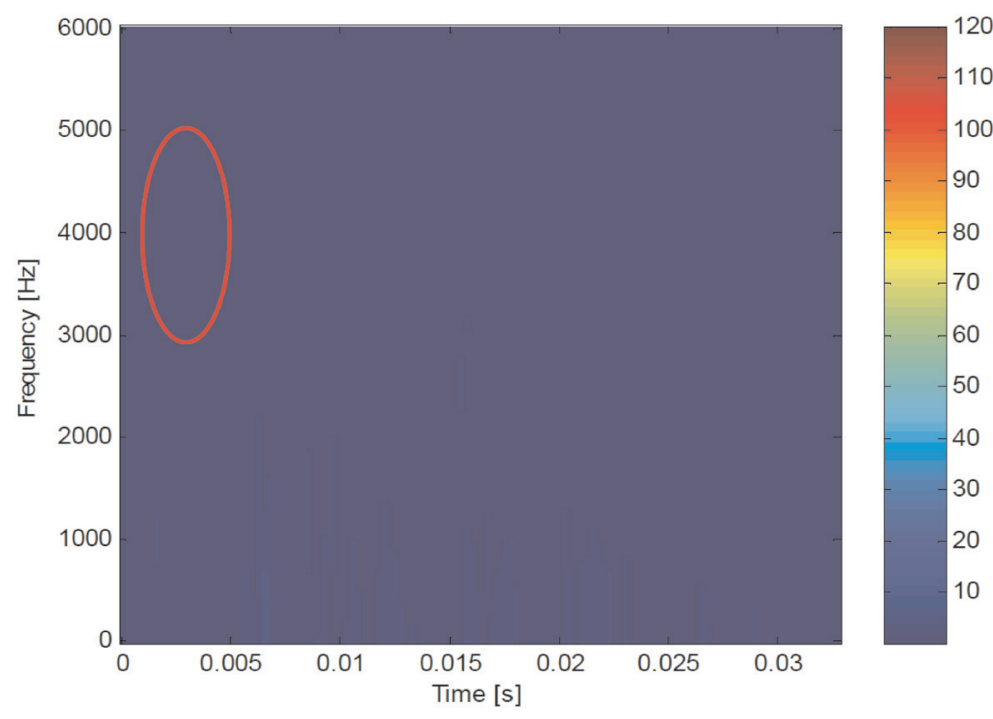

Fig. 1. The example vibration acceleration courses in the $\mathrm{Z}$ dimension $\left(\mathrm{a}_{\mathrm{z}}\right.$ ) of cylinder heads for the $2112 \mathrm{SSF}$ diesel locomotive engine $\left(\mathrm{n}=700 \mathrm{rpm}\right.$ and $\left.\mathrm{M}_{0}=0 \mathrm{~N} \cdot \mathrm{m}\right)$ and for lack of combustion

Rys. 1. Przykładowy przebieg przyspieszeń drgań w kierunku Z (a) głowic silnika 2112 SSF lokomotywy spalinowej $\left(n=700 \mathrm{obr} / \mathrm{min}\right.$ i $\left.M_{0}=0 \mathrm{~N} \cdot \mathrm{m}\right)$ dla braku spalania może być przyrównany do filtracji z zastosowaniem stałej względnej szerokości pasma $\Delta \mathrm{f} / \mathrm{f}_{\mathrm{s}}$. Położenie filtra na mapie czasowo-częstotliwościowej jest określone parametrami skali i transpozycji (a - skala, b - transpozycja). Szerokość analizowanego pasma zwiększa się wraz z transpozycją do większych częstotliwości (rozdzielczość analizy w dziedzinie częstotliwości zmniejsza się). Następnie rozdzielczość w dziedzinie czasu zwiększa się i odwrotnie. Powyższa właściwość jest użyteczna w sytuacji jednoczesnej analizy i obserwacji z różnym krokiem czasowym dla szybkozmiennych i wysokoczęstotliwościowych procesów oraz niskoczęstotliwościowych procesów o niewielkiej prędkości. Do wad metody należą: forma wyników zależy od przyjętej funkcji bazowej (macierzystej), a interpretacja formy graficznej nie zawsze jest intuicyjna.

Dystrybucja Wignera-Ville'a (WVD) jest realizowana z zastosowaniem dwuwymiarowego okna czasowo-częstotliwościowego. Ten rodzaj analizy umożliwia teoretycznie dobór okna analizy o każdym rozmiarze. Jeżeli rozmiar okna analizy jest określony w sposób dowolny, może to dać ujemne wartości rozkładu, zwiększające stopień interferencji w dziedzinie czasu i częstotliwości, co czyni bardziej trudnym proces interpretacji wyników. Transformacja WVD charakteryzuje się długim czasem obliczeń w porównaniu do poprzednich metod, zwłaszcza dla większych przebiegów czasowych sygnałów.

Zadaniem procedur selekcji czasowo-częstotliwościowej jest uzyskanie i/lub przedstawienie informacji związanych ze spalaniem w cylindrze silnika z zastosowaniem procesów drganiowych. Poza przetwornikami drgań za-

a long time of the calculations, especially for long time series, comparing to the previous methods.

The task of time-spectral selection procedures is to get out from the vibration process and/or display pieces of information connected with the combustion process in an engine cylinder. Apart from vibration transducers, the tachometric transducer was used in the phenomenon area to identify the cycle phases during the engine work. In order to decrease the estimation errors of amplitude and frequency components for map a(t, f), the amplitudefrequency correction procedures can be used as an option. Further signal parameterization should lead up to obtain symptoms that detect misfire events in an engine cylinder.

The application of a time-spectral map parameterization is necessary to obtain a complete representation of a lack of ignition in a cylinder on the based on point measures of a vibration signal. The second measure-

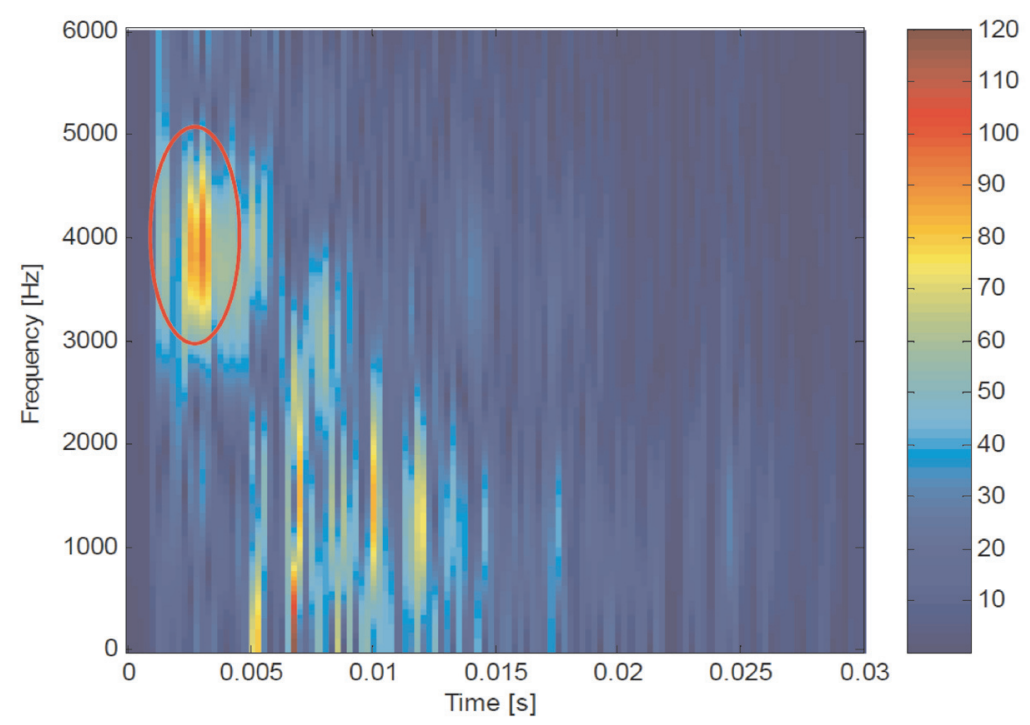

Fig. 2. The example vibration acceleration courses in the $\mathrm{Z}$ dimension $\left(\mathrm{a}_{\mathrm{z}}\right)$ of cylinder heads for the $2112 \mathrm{SSF}$ diesel locomotive engine $\left(\mathrm{n}=700 \mathrm{rpm}\right.$ and $\left.M_{0}=0 \mathrm{~N} \cdot \mathrm{m}\right)$ and for a combustion process

Rys. 2. Przykładowy przebieg przyspieszeń drgań w kierunku Z (a) głowic silnika 2112 $\mathrm{SSF}$ lokomotywy spalinowej $\left(n=700 \mathrm{obr} / \mathrm{min} i M_{o}=0 \mathrm{~N} \cdot \mathrm{m}\right)$ dla normalnego spalania 
ment stage was conducted on a 2112 SSF diesel locomotive engine (in regular operation). The time-spectral maps were obtained, both for a lack of combustion in a cylinder (Fig. 1) and when combustion took place (Fig. 2). In this case, a peak value of vibration accelerations in the range of frequency of 3000-5000 Hz, determined based of timespectral map, was the parameter that described a lack of ignition in the cylinder or a combustion process for a diesel locomotive engine. Parameter changes were described with the dynamics of $34 \mathrm{~dB}$.

\section{Non-linear diagnostics of engine combustion through a vibration signal}

Choice of time delay and embedding dimension

Time delay $t$ was calculated both as the first zero cross of autocorrelation function (COR) and first minimum of averaged mutual information (AMI). The eventual value of $\mathrm{t}$ was usually taken from AMI because it represents real nonlinear properties (Fig. 3). Eventually, the decision as to which value must be selected resulted from the necessity of using the same (or similar) values of parameters for compared stosowano znacznik kąta w obszarze rozważanego zjawiska, celem uzyskania cykli pracy silnika podczas jego pracy.

W celu zmniejszenia błędów oceny składowych amplitudowych i częstotliwościowych mapy a(t, f), można zastosować procedury korekcji amplitudowo-częstotliwościowej. Dalsza parametryzacja sygnału powinna doprowadzić do uzyskania symptomów umożliwiających wykrycie braku zapłonu w cylindrze silnika.

Zastosowanie parametryzacji mapy czasowo-częstotliwościowej jest niezbędne do uzyskania pełnej reprezentacji braku zapłonu w cylindrze na podstawie miar punktowych sygnału drganiowego. Drugi etap badań przeprowadzono na silniku 2112 SSF lokomotywy spalinowej (będącej w eksploatacji). Mapy czasowo-częstotliwościowe otrzymano zarówno dla braku spalania w silniku (rys. 1), jak i dla procesu spalania (rys. 2). W tym przypadku wartość szczytowa przyspieszeń drgań w paśmie 3000-5000 Hz, wyznaczona na podstawie mapy czasowo-częstotliwościowej, była parametrem opisującym brak zapłonu w cylindrze lub proces spalania dla silnika lokomotywy. Dynamika zmian parametru była równa $34 \mathrm{~dB}$. a)

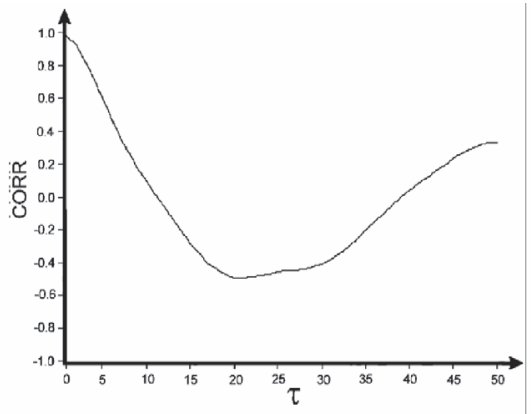

b)

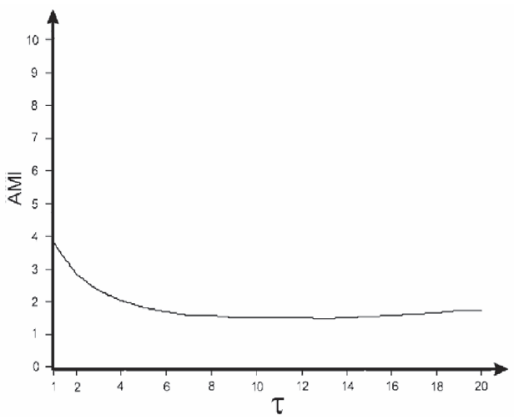

c)

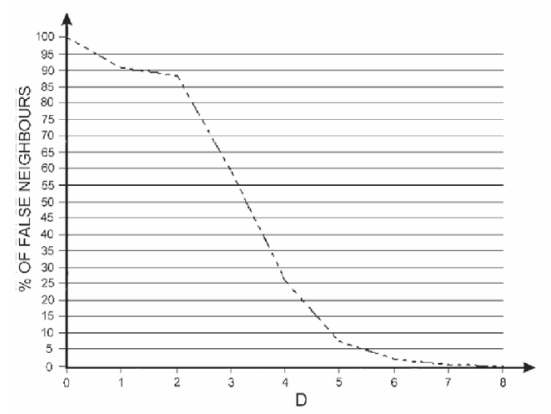

Fig. 3. Exemplary plot of autocorrelation function (a), averaged mutual information (b) and dependence false neighbour percentage on dimension D for $16 \mathrm{H} 12 \mathrm{~A}$ engine $(\mathrm{n}=1500 \mathrm{rpm}, \mathrm{Z}$ direction, all cylinder work)

Rys. 3. Przykładowy przebieg funkcji autokorelacji (a), uśrednionej informacji wzajemnej (b) i zależności względnego udziału fatszywych sąsiadów od wymiaru D dla silnika $16 H 12 \mathrm{~A}(\mathrm{n}=1500 \mathrm{obr} / \mathrm{min}$, kierunek $\mathrm{Z}$, proces spalania we wszystkich cylindrach)

signals. In turn, dimension d was obtained using the method. During the analysis and finding the embedding dimension $\mathrm{d}$, we took into account the dependence of the false neighbor percentage on dimension $d$ and considered the two cases at the beginning: while the plot decreases till value 5\%, while the plot decreases till value $0 \%$. It appeared that the second case $(0 \%)$ was very difficult to estimate. The decrease of the plot till real $0 \%$ was not strict and well marked, and the calculations usually were very time-consuming. The level $5 \%$ was enough because this usually indicated the area where the plot reached the plateau.

For the obtained signals, the time-delay value was in the range $t=12-14\left(\right.$ where $\left._{t}=12.78\right)$, and the embedding dimension $d=5-6\left(\right.$ where $\left.d_{s r}=5.5\right)$. The obtained values of $t$ and $\mathrm{d}$ allow observing the time evolution in the phase space. Most of the observed geometrical objects have the form of spheres, but many of them show some subtle structures (Fig. 4-6). The vibroacoustic signals were preprocessed with the

\section{Diagnostyka nieliniowa procesu spalania w silniku z zastosowaniem sygnału drganiowego}

Wybór opóźnienia czasowego i wymiaru ,zanurzenia"

Opóźnienie czasowe t obliczono jako pierwsze miejsce zerowe funkcji autokorelacji (COR - autocorrelation function) oraz pierwsze minimum uśrednionej informacji wzajemnej (AMI - averaged mutual information). Ostateczną wartość t zazwyczaj wybiera się z AMI ze względu na to, iż reprezentuje ona rzeczywiste właściwości nieliniowe (rys. 3). Decyzję o tym, jaka wartość ma być wybrana podjęto na podstawie konieczności zastosowania tych samych (lub zbliżonych) wartości parametrów dla porównanych sygnałów. Z kolei wymiar d uzyskano z zastosowaniem powyższej metody. Podczas analizy i poszukiwania wymiaru „zanurzenia” d, brano pod uwagę zależność względnego procentowego udziału fałszywych sąsiadów od wymiaru d i rozważono na początek dwa przypadki: gdy przebieg wykresu podąża do uzyskania wartości 5\%, gdy przebieg wykresu podąża 
a)

b)
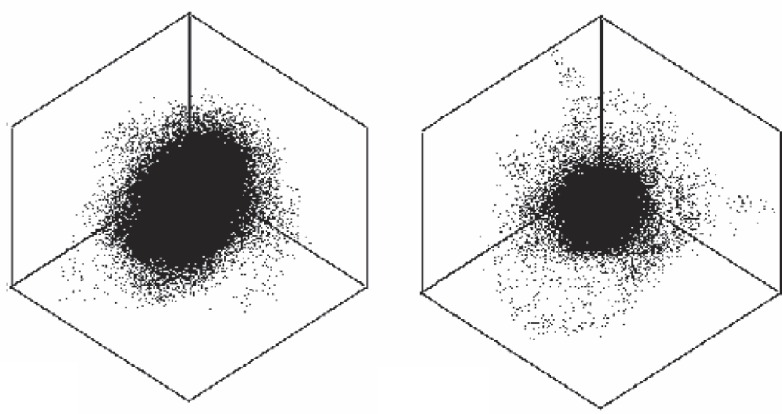

Fig. 4. The phase portrait in a three-dimensional-phase space which is the projection from the multidimensional space: a - for the pure (without filtration) signal $(\mathrm{n}=650 \mathrm{rpm})$, cylinder 4 does not work, direction $X(\tau=12$ and $d=6)$ and $b-$ for the same signal after filtration $(\tau=5$ and $\mathrm{d}=6)$

Rys. 4. Obraz fazowy w trójwymiarowej przestrzeni fazowej jako rzut obrazu z przestrzeni wielowymiarowej: $a$-dla sygnatu bez filtracji $(n=650 \mathrm{obr} / \mathrm{min})$, cylinder $4 \mathrm{bez}$ spalania, kierunek $X(\tau=12$ i $d=6)$ $i b-$ sygnat poddany filtracji $(\tau=5$ id $=6)$

use of the band filters FIR and IIR (Butterworth) a constant component is cut off, and the dominant frequency band is the same for all signals. The IIR filters for our signals appeared unstable and during the filter designing there was no influence on the phase characteristic. Eventually, the FIR filters could be used, which are better from the stability point of view and have a linear phase characteristic.

The main disadvantage of FIR filter is the necessity of using high order methods, which appeared very time consuming. This unfortunately obtained by applying the filter twice, forward and backward [10]. The filtrating results appear especially interesting for the calculated Lyapunov exponents. The filtering decreased the values of the time delay and also the embedding dimension. In time evolution

a)

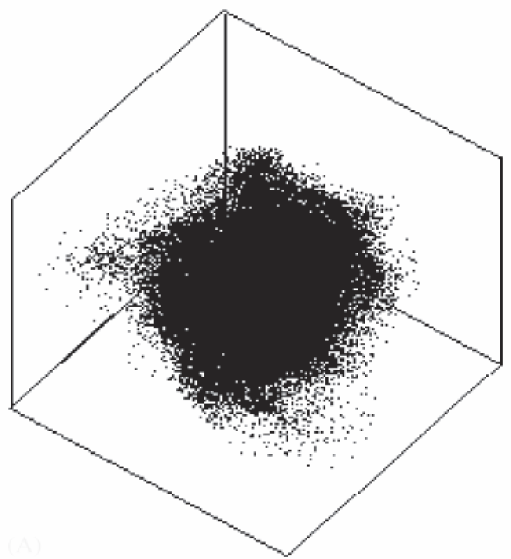

b)

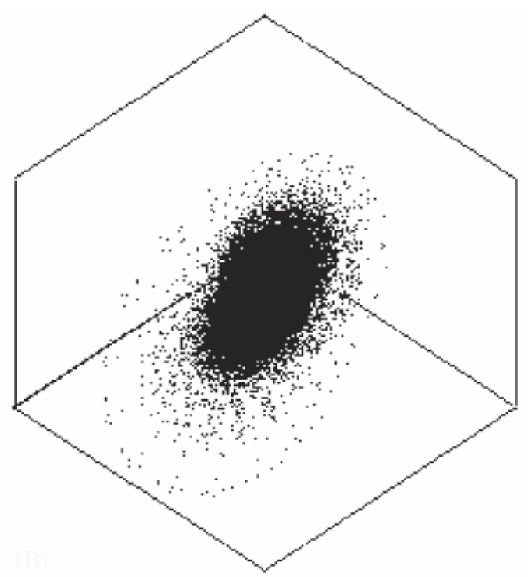

Fig. 6. The phase portrait in a three-dimensional-phase space which is the projection from the multidimensional space: $\mathrm{a}$ - for the pure (without filtration) signal $1500 \mathrm{rpm}$, all cylinders work, direction $\mathrm{Z}$ ( $\tau=13$ and $d=5$ and $b-$ for the same signal after filtration $(\tau=9$ and $d=6)$

Rys. 6. Obraz fazowy w trójwymiarowej przestrzeni fazowej jako rzut obrazu z przestrzeni wielowymiarowej: a - dla sygnatu bez filtracji $(n=1500 \mathrm{obr} / \mathrm{min})$, wszystkie cylindry ze spalaniem, kierunek $Z(\tau=13$ id $=5)$ i $b-$ sygnat poddany filtracji $(\tau=9$ i $d=6)$ b)

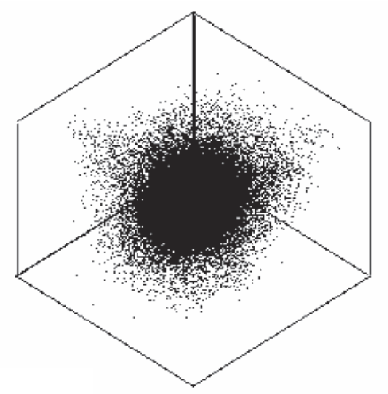

Fig. 5. The phase portrait in a three-dimensional-phase space which is the projection from the multidimensional space: a - for the pure without filtration) signal $(\mathrm{n}=1100 \mathrm{rpm})$, all cylinders work, direction $\mathrm{Y}$ $(\tau=13$ and $d=5)$ and $b-$ for the same signal after filtration

$$
(\tau=4 \text { and } \mathrm{d}=6)
$$

Rys. 5. Obraz fazowy w trójwymiarowej przestrzeni fazowej jako rzut obrazu z przestrzeni wielowymiarowej: a - dla sygnatu bez filtracji ( $\mathrm{n}=1100 \mathrm{obr} / \mathrm{min})$, wszystkie cylindry ze spalaniem, kierunek $Y$ $(\tau=13$ id $=5)$ i $b-$ sygnat poddany filtracji $(\tau=4 i d=6)$

do wartości $0 \%$. W drugim przypadku $(0 \%)$ odnotowano trudności w oszacowaniu wartości. Obniżanie się przebiegu wykresu do wartości $0 \%$ nie było dokładne i dobrze rozpoznawalne, a obliczenia zazwyczaj czasochłonne. Poziom wynoszący 5\% był wystarczający, ponieważ zazwyczaj wskazywał na obszar, gdzie wykres osiągał plateau.

Dla uzyskanych sygnałów wartość opóźnienia czasowego mieściła się $\mathrm{w}$ zakresie $\mathrm{t}=12-14\left(\mathrm{t}_{\mathrm{sr}}=12,78\right)$, a wymiar „zanurzenia” $d=5-6\left(d_{\text {śr }}=5,5\right)$. Uzyskane wartości t i d umożliwiają obserwację zmian czasu w przestrzeni fazowej. Większość zaobserwowanych obiektów geometrycznych ma formę kulistą, lecz część z nich ma niewielkie struktury (rys. 4-6). Sygnały wibroakustyczne przetworzono z zastosowaniem filtrów FIR i IIR (Butterworth), które odcinają składową stałą, a dominujące pasmo częstotliwości jest takie samo dla wszystkich sygnałów. Filtry IIR dla rozważanych sygnałów okazały się niestabilne, a w trakcie projektowania filtra nie odnotowano jego wpływu na charakterystykę fazową. Ostatecznie można było zastosować filtry FIR, które są bardziej stabilne i mają liniową charakterystykę fazową.

Główną wadą filtra FIR jest konieczność zastosowania metod analizy wyższych rzędów, które są czasochłonne. Powoduje to tym samym, iż niemożliwe jest zastosowanie ich $\mathrm{w}$ ciągłej analizie sygnału. W praktyce można rozważać zastosowanie filtra IIR Butterwortha $z$ fazą zerową, który może być uzyskany przez zastosowanie filtra dwukrotnie, na początki i na końcu [10]. Wyniki filtrowania okazały się interesujące naukowo, 
a)

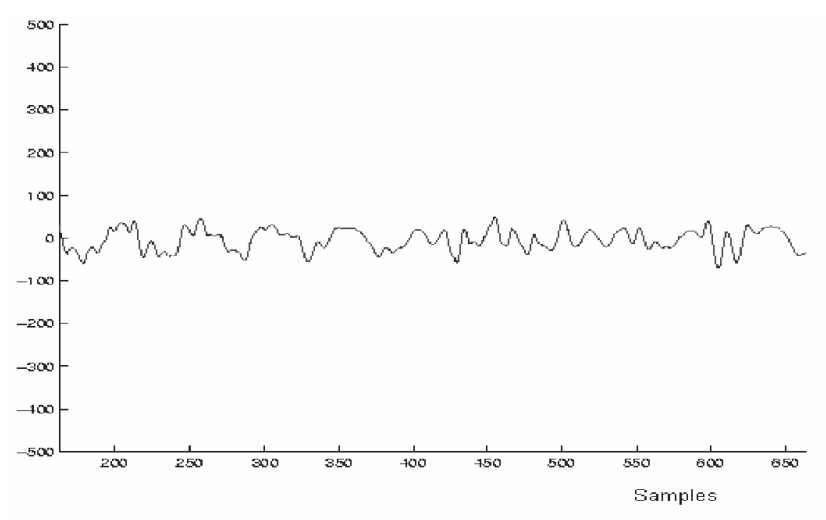

c)

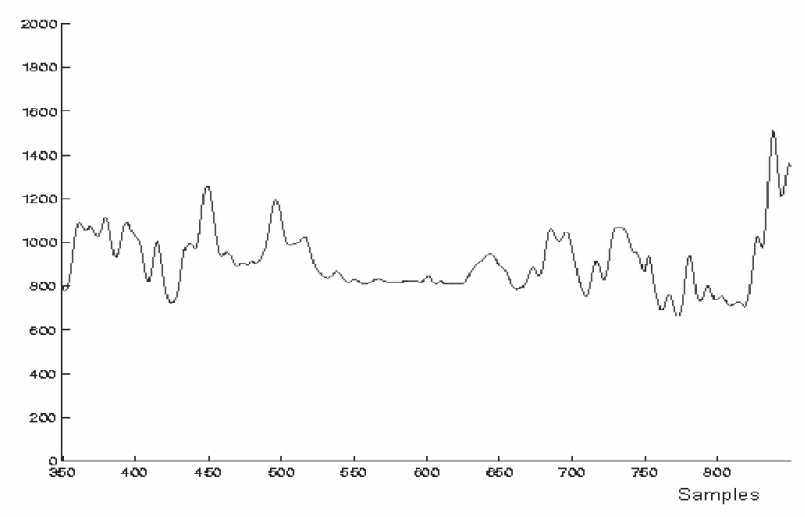

b)

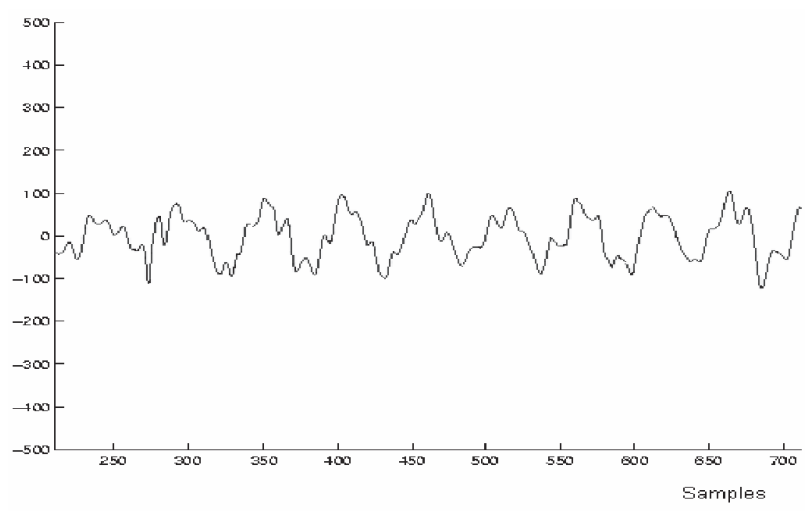

d)

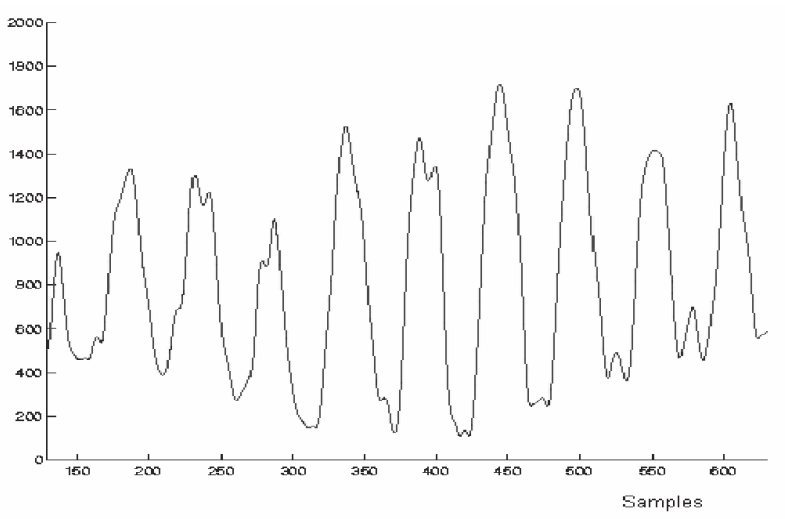

Fig. 7. Examples of plots of signals for $1500 \mathrm{rpm}$ and all cylinders working (a), for 1 cylinder with misfires (b) and plots of their STFT spectrum (c) and (d) correspondingly (in the 2000 samples window)

Rys. 7. Przykładowe przebiegi sygnałów dla $n=1500 \mathrm{obr} /$ min dla następujących przypadków: wszystkie cylindry ze spalaniem (a), cylinder 1 z brakiem zaptonu (b) oraz odpowiadające im widma STFT (c) i (d) (okno zawiera 2000 próbek sygnatów)

Table 2. The mean coordinates of centers of 7-dimensional parameter space for signals with combustions and with misfire events for $16 \mathrm{H} 12 \mathrm{~A}$ engine

Tablica 2. Średnie wspótrzędne środków 7-wymiarowej przestrzeni parametrów dla sygnałów ze spalaniem i z wypadaniem zapłonu dla silnika $16 \mathrm{H} 12 \mathrm{~A}$

\begin{tabular}{|c|c|c|c|c|c|c|c|c|}
\hline & \multirow{2}{*}{$\begin{array}{l}\text { Window/ } \\
\text { okno }\end{array}$} & 1 & 2 & 3 & 4 & 5 & 6 & 7 \\
\hline & & Fourier 2 & Fourier 3 & Fourier 4 & Fourier 5 & Fourier 6 & Mean & Variance \\
\hline \multirow{2}{*}{$\begin{array}{l}\text { All cylinders with combu- } \\
\text { stion/wszystkie cylindry ze } \\
\text { spalaniem }\end{array}$} & $0.1 \mathrm{~s}$ & 628.93 & 526.62 & 550.79 & 660.96 & 513.13 & 3.50 & 365.10 \\
\hline & $0.01 \mathrm{~s}$ & 428.42 & 652.82 & 1366.78 & 2854.60 & 1156.40 & 0.37 & 7.23 \\
\hline \multirow{2}{*}{$\begin{array}{l}\text { Cylinder } 1 \text { with misfires/cy- } \\
\text { linder } 1 \text { z brakiem zaptonu }\end{array}$} & $0.1 \mathrm{~s}$ & 552.87 & 537.14 & 819.78 & 703.86 & 460.463 & -0.78 & 233.26 \\
\hline & $0.01 \mathrm{~s}$ & 542.48 & 869.75 & 1656.60 & 3487.70 & 1876.68 & -0.08 & 69.00 \\
\hline
\end{tabular}

plots we can also see some small differences. The process of filtering always gives some questions and doubts. Both the observation of the signal plot and the view of the time evolution in the phase space show that our signals are very noisy. This is always a problem how to denoise signal. Usually, a filtering leads to a loss of some signal components and we never know whether we have eliminated some important and relevant components. zwłaszcza dla obliczonych wykładników Lapunowa. Proces spowodował zmniejszenie wartości opóźnienia czasowego i wymiaru ,zanurzenia”. W przebiegach zmian czasu są widoczne również niewielkie różnice. Proces filtrowania zawsze nasuwa wiele pytań i wątpliwości. Obie obserwacje przebiegu sygnału i obraz zmian czasu w przestrzeni fazowej wskazują na duże zaszumienie sygnałów. Zawsze istnieje problem właściwego usunięcia składowej z szumem. 
Table 3. The results of the dominant Lyapunov exponents calculation for the case with all cylinder working and with one cylinder disconnected Tablica 3. Wyniki obliczeń maksymalnych wykładników Lapunowa, gdy we wszystkich cylindrach jest spalanie oraz dla jednego cylindra bez spalania

\begin{tabular}{|c|c|c|c|}
\hline \multirow{2}{*}{$\begin{array}{l}\text { Engine velocity in [rpm] and sensor } \\
\text { number/prędkość obrotowa silnika } \\
\text { w [obr/min] i numer przetwornika }\end{array}$} & \multicolumn{3}{|c|}{$\begin{array}{l}\text { Dominant Lyapunov exponent/maksymalny wyktadnik } \\
\text { Lapunowa }\end{array}$} \\
\hline & $\begin{array}{l}\text { All cylinder working/spalanie } \\
\text { we wszystkich cylindrach }\end{array}$ & $\begin{array}{l}\text { One cylinder disconnected/ } \\
\text { jeden cylinder bez spalania }\end{array}$ & Difference/różnica \\
\hline 15001 & 0.573 & 0.519 & 0.054 \\
\hline 15002 & 0.292 & 0.197 & 0.095 \\
\hline 15003 & 0.524 & 0.500 & 0.024 \\
\hline 11001 & 0.581 & 0.542 & 0.039 \\
\hline 11002 & 0.355 & 0.327 & 0.028 \\
\hline 11003 & 0.417 & 0.501 & -0.084 \\
\hline 6501 & 0.456 & 0.385 & 0.071 \\
\hline 6502 & 0.262 & 0.299 & -0.037 \\
\hline 6503 & 0.508 & 0.434 & 0.074 \\
\hline
\end{tabular}

Figure 7 presents the fragments of engine signal plots and corresponding second line of a STFT spectrum plots. The important differences between the centers for signals with combustion and for cylinder with misfires are presented in the Table 2 and the dominant Lyapunov exponents are shown in the Table 3.

\section{Conclusions}

The research conducted on the diesel locomotive engines with the use of JTFA method allowed stating that:

- the method allows assessing a lack of ignition, both for a single cylinder research engine and multi-cylinder engine of a diesel locomotive,

- the time, process and frequency domain analyses ought to be used for misfire diagnosis,

- the dimensional point measures of the vibroacoustic process can describe changes occurring as a result of the misfire very well. They may constitute the basis for the realization of the diagnostic procedure of misfire detection within on-board diagnostics,

- the research at the potential operating conditions for a diesel locomotive engine confirmed a high precision and quality of the misfire detection (for each cylinder) with the help of the vibration acceleration,

- the JTFA method is characterized by a high dynamics of parameter changes, which reflects the ignition occurrence or its lack in an engine cylinder (34 dB for the $2112 \mathrm{SSF}$ engine),

- the relative error of a method did not exceed $10 \%$ for the examined engines.

The tests on the 16H12A diesel locomotive engine gave the following conclusions:

- values of the dominant Lyapunov exponents were within the range $0.2-0.5$. The increase in the dominant Lyapunov exponents was for the improper signals - by $17.9 \%$ on average, which indicates an increase in the misfire chaotic component.

- the most stable and univocal results were obtained for the engine speed of $n=1500 \mathrm{rpm}$ (the average increase by $16.5 \%$ ) and for $1100 \mathrm{rpm}$ (the average increase by $4.6 \%$ ).
Zazwyczaj proces filtrowania doprowadza do utraty wybranych składowych sygnału i nigdy nie wiadomo, czy dzięki temu nie usuwana jest składowa niosąca ważne informacje o danym procesie.

Na rysunku 7 przedstawiono fragmenty przebiegów sygnałów uzyskanych z silnika i odpowiadające im (w drugim rzędzie) przebiegi widma STFT. Istotne różnice pomiędzy rzędami dla sygnałów od spalania i braku zapłonu zamieszczono w tab. 2, a wartości maksymalnych wykładników Lapunowa przedstawiono $\mathrm{w}$ tab. 3.

\section{Podsumowanie}

Badania przeprowadzone na silnikach lokomotyw spalinowych z zastosowaniem metody JTFA pozwoliły na stwierdzenie, iż:

- metoda umożliwia ocenę braku zapłonu, zarówno dla jednocylindrowego silnika badawczego, jak i wielocylindrowego silnika lokomotywy spalinowej,

- analizy w zakresie czasu, procesu i częstotliwości należy zastosować do diagnostyki wypadania zapłonów,

- wymiarowe miary punktowe procesów wibroakustycznych opisują dokładnie zmiany zachodzące podczas występowania zjawisk wypadania zapłonów, estymaty punktowe mogą stanowić podstawę do realizacji procedury diagnostycznej wykrywania wypadania zapłonów z zastosowaniem diagnostyki pokładowej,

- badania zrealizowane w potencjalnych warunkach eksploatacji dla silnika lokomotywy spalinowej potwierdziły dużą dokładność i jakość wykrycia wypadania zapłonów (dla każdego cylindra) z zastosowaniem przyspieszeń drgań,

- metoda JTFA charakteryzuje się dużą dynamiką zmian parametru, który odnosi się do pojawienia się bądź braku spalania w silniku (34 dB dla silnika 2112 SSF),

- względny błąd metody nie przekracza $10 \%$ dla badanych silników.

Badania przeprowadzone na silniku 16H12A lokomotywy dowiodły, iż:

- wartości maksymalnych wykładników Lapunowa wyniosły 0,2-0,5. Wzrost powyższych wykładników odnotowa- 
- for $650 \mathrm{rpm}$ the average increase was by $32.7 \%$, but in this case the results were unstable and the $t$ time-delay values differed for both proper and improper cases. It should also be remembered that in an idle run the operating conditions were very unstable.

- taking into consideration only the signals for 1100 and $1500 \mathrm{rpm}$, the measurements for three sensor directions were as follows:

- for the direction horizontal-transverse to the main locomotive axis the average increase of the dominant Lyapunov exponent was $4.75 \%$,

- for the direction parallel to the main locomotive axis the average increase of the dominant Lyapunov exponent was $19.6 \%$,

- for the direction vertical-transverse to the main locomotive axis the average increase of dominant Lyapunov exponent: $7.4 \%$.

The results of the research with the use of non-linear methods appear quite interesting. First of all, the dominant Lyapunov exponents for all signals were positive, which means that we can find some chaotic components in the signals and their dynamics. The calculated values of time delay $\tau$ and dimension $\mathrm{d}$ appeared quite reasonable. The $\mathrm{d}$ was moderately high which gives a hope to find some low-dimensional chaotic behavior. It is worth underlining that there exists a significant difference in the dominant Lyapunov exponents for the case with all cylinders working and the case with one cylinder disconnected. Taking into account the measurement presented in the paper and literature data we can conclude that the Lyapunov exponents can be used as diagnostic parameters. The only problem is to perform the good and reasonable reprocessing consisting of denoising and filtering. But the reprocessing should be performed with a great care because any inconsiderate elimination of some signal components can eliminate relevant dynamic information. Also some interesting behavior was observed during the use of the false nearest neighbor method. The result dimension of the method depends on the criterion threshold, which classifies neighbors as false or true. In the plot of dimension $d$ against the criteria threshold we can find a broad plateau, which gives the possibility of a reasonable choice of the threshold and result dimension.

Paper reviewed/Artykut recenzowany no przy braku zapłonu - średnio o 17,9\%, co wskazuje na wzrost składowej chaotycznej braku zapłonu,

- najbardziej stabilne i ogólne wyniki uzyskano dla prędkości obrotowej silnika $\mathrm{n}=1500 \mathrm{obr} / \mathrm{min}$ (średni wzrost o $16,5 \%$ ) i dla $1100 \mathrm{obr} / \mathrm{min}$ (średni wzrost o 4,6\%),

- dla prędkości równej $650 \mathrm{obr} / \mathrm{min}$ średni wzrost wykładników wyniósł $32,7 \%$, lecz w tym przypadku wyniki były niestabilne, a wartości t opóźnienia czasowego różniły się dla spalania i braku zapłonu. Należy również odnotować, iż warunki pracy dla biegu jałowego były bardzo niestabilne,

- biorąc pod uwagę jedynie sygnały uzyskane dla 1100 obr/min i $1500 \mathrm{obr} / \mathrm{min}$, można odnotować następujące zależności dla trzech wybranych kierunków rejestracji sygnałów:

- średni wzrost maksymalnego wykładnika Lapunowa dla kierunku Y wyniósł 4,75\%,

- dla kierunku Z średni wzrost maksymalnego wykładnika Lapunowa wyniósł 19,6\%,

- dla kierunku X średni wzrost maksymalnego wykładnika Lapunowa wyniósł 7,4\%.

Wyniki badań z zastosowaniem metod nieliniowych okazały się interesujące naukowo. Po pierwsze, maksymalne wykładniki Lapunowa dla wszystkich sygnałów były dodatnie, co oznacza, iż można odnaleźć składowe chaotyczne w sygnale i ich dynamikę. Obliczone wartości opóźnienia czasowego $\tau$ i wymiaru d okazały się uzasadnione. Wymiar d nie był zbyt duży, dzięki czemu możliwe jest odnalezienie niskowymiarowego zachowania chaotycznego. Należy podkreślić występowanie znaczących różnic w maksymalnych wykładnikach Lapunowa dla wszystkich cylindrów pracujących w sposób prawidłowy i dla przypadku braku spalania w cylindrze. Biorąc pod uwagę przeprowadzone badania $i$ dane literaturowe, można wnioskować, iż wykładniki Lapunowa można zastosować jako parametry diagnostyczne. Jedyną trudnością jest uzyskanie dobrego i racjonalnego przetwarzania sygnałów, uwzględniającego proces usunięcia składowej związanej z szumem, i filtrowania. Należy przeprowadzić przetwarzanie sygnałów ze szczególną troską z uwagi na nierozważne usunięcie składowych sygnałów zawierających użyteczne informacje o procesie dynamicznym. Zaobserwowano ponadto interesujące zachowanie podczas zastosowania metody fałszywych najbliższych sąsiadów. Ostateczny wymiar metody zależy od wartości granicznej kryterium, która klasyfikuje sąsiadów jako fałszywych lub prawdziwych. Graficzne przedstawienie zmian wymiaru d w odniesieniu do wartości granicznej kryterium pozwala na odnalezienie głównego plateau, dzięki czemu możliwy jest właściwy wybór wartości granicznej i ostatecznego wymiaru.

\section{Nomenclature/Skróty i oznaczenia}

a scale a parameter connected with a placement in the frequency domain/skala - parametr związany z położeniem $w$ dziedzinie częstotliwości

AFC amplitude-frequency correction/korekcja aplitudowo-częstotliwościowa
AMI averaged mutual information/uśredniona informacja wzajemna

b parameter that points at a position in the time domain (translation)/parametr określajacy położenie $w$ dziedzinie czasu (translacja)

CI compression-ignition/zapłon samoczynny 
COR correlation function/funkcja korelacji

d dimension of the state space/wymiar przestrzeni stanu

D cylinder bore/średnica cylindra

simple operation of the discrete Fourier transform/prosta operacja dyskretnego przeksztatcenia Fouriera

EOBD European On-Board Diagnostics/europejski system diagnostyki poktadowej

$\varepsilon \quad$ compression ratio/stopień sprężania

FFT Fast Fourier Transform/szybkie przeksztatcenie Fouriera

FIR finite impulse response/skończona odpowiedź impulsowa

HDV Heavy-Duty Vehicles/pojazdy ciężarowe o dopuszczalnej masie calkowitej powyżej $3500 \mathrm{~kg}$

IIR infinite impulse response/nieskończona odpowiedź impulsowa

JTFA Joint Time-Frequency Analysis/analiza czasowo-czestotliwościowa

$\lambda \quad$ Lyapunov exponent/wyktadnik Lapunowa

$\mathrm{M}_{\mathrm{o}} \quad$ torque/moment obrotowy

n revolutions per minute/prędkość obrotowa

OBD On-Board Diagnostics/diagnostyka pokładowa
OBD II On-Board Diagnostics II (second generation)/diagnostyka poktadowa drugiej generacji

$\mathrm{p}_{\mathrm{wtr}} \quad$ injection opening pressure/ciśnienie otwarcia wtryskiwacza

S cylinder stroke/skok ttoka

$\mathrm{s}(\mathrm{t}) \quad$ sampled time signal run/wybrany przebieg czasowy sygnatu

STFT Short Time Fourier Transform/krótkoczasowe przeksztatcenie Fouriera

t time, dynamic period/czas, okres dynamiczny

$\mathrm{t}_{\mathrm{p}} \quad$ sample time/czas próbkowania

$\mathrm{t}$ position of the time window in the time domain, time delay in non-linear analysis/położenie okna czasowego $w$ dziedzinie czasu, opóźnienie czasowe $w$ analizie nieliniowej

$\mathrm{V}_{\mathrm{ss}} \quad$ engine displacement/objętość skokowa silnika

$\mathrm{w}(\mathrm{t})$ time window function (weighing function)/funkcja okna czasowego (funkcja wagowa)

WT Wavelet Transform/przeksztatcenie falkowe

WVT Wigner Ville Distribution/dystrybucja Wigner-Ville'a

\section{Bibliography/Literatura}

[1] Baker G.L., Gollub, J.P.: Wstęp do dynamiki układów chaotycznych. Wydawnictwa Naukowe PWN, Warszawa 1998.

[2] Barczewski R.: AFC - the method of amplitude spectrum correction. Congress of Technical Diagnostics, Gdańsk 1996.

[3] Barczewski R.: Analiza nieliniowości z zastosowaniem STSFAFC jako metoda diagnozowania. II International Congress of Technical Diagnostics Warsaw, Poland 19-22 September 2000.

[4] Barczewski R.: Application of the Short Time Fourier Transform (STFT) with Amplitude and Frequency Correction (AFC) to non-linear system free vibration signal analysis. Report: CRI Hannover-DAAD, November 1997.

[5] Iokibe T.: Industrial Application of Chaos Engineering. 2nd On-line Conference on Soft Computing in Engineering Design and Manufacturing (WSC2), 23-27 June 1997.

[6] Jerrelind J., Stensson A.: Nonlinear dynamics of parts in engineering systems. Chaos, Solitons and Fractals, 11, 2000, 2413-2428.

[7] Li W., Gu F., Ball D., Leung A.Y.T, Phipps C.E.: A study of the noise from diesel engines using the independent component analysis. Mechanical Sytems and Signal Processing (2001) 15(6), pp. 1165-1184.

[8] Luo G., Xie J.: Bifurcations and chaos in a system with impacts. Physcia D, 148, 2001, 183-200.

[9] Marwala T., Hunt H.E.M.: Is damage identification using vibration data in a population of cylinders feasible? Journal of Sound and Vibration (2000) 237(4), p. 727-732.
[10] Mitra, S.K., Kaiser J.F. (eds.): Handbook for Digital Signal Processing. John Wiley \& Sons, 1993.

[11] Newland D.E.: Practical Signal Analysis: Do Wavelets make any difference? Proceedings of DTC'97 1997 ASME Design Engineering Technical Conference, September 14-17, 1997 Sacramento, California.

[12] Ott E.: Chaos w układach dynamicznych. WNT, Warszawa 1997.

[13] Rhodes C., Morari M.: False-nearest-neighbors algorithm and noise-corrupted time series, Physical Review E 55 (1997) 6162-6170.

[14] Roberts J.B., Peyton Jones J.C., Landsborough K.L.: Stochastical modelling and estimation for cyclic pressure variations in spark ignition engines. Mechanical Systems and Signal Processing (2001) 15(2), p. 419-438.

[15] Shie Qian, Dapang Chen: Joint Time-Frequency analysis. Methods and Applications, Prentice Hall PTR Inc. 1996.

[16] Wang W.J, Chen J., Wu X.K., Wu Z.T.: The application of some non-linear methods in rotating machinery fault diagnosis. Mechanical Sytems and Signal processing (2001) 15(4), 697-705.

[17] Yang J., Pu L., Wang Z., Zhau Y., Yan X.: Fault detection in a Diesel engine by analysing the instantaneous angular speed. Mechanical Systems and Signal Processing (2001) 15(3), p. 549-564.
Prof. Jerzy Merkisz, DSc., DEng., - Professor in the Faculty of Working Machines and Transportation at Poznan University of Technology.

Prof. Jerzy Merkisz - profesor na Wydziale Maszyn Roboczych i Transportu Politechniki Poznańskiej.

e-mail: jerzy.merkisz@put.poznan.pl

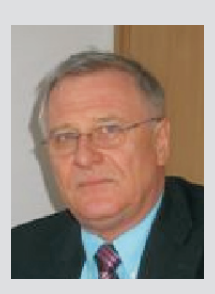

Marek Waligórski, DEng. - Doctor in the Faculty of Working Machines and Transport at Poznan University of Technology.

Dr inż. Marek Waligórski - adiunkt na Wydziale Maszyn Roboczych i Transportu Politechniki Poznańskiej.

e-mail:marek.waligorski@put.poznan.pl 